\title{
From test pits to big-scale archaeology in New Caledonia, southern Melanesia
}

\author{
Christophe Sand, David Baret, Jacques Bolé, Stéphanie Domergue, \\ André-John Ouetcho and Jean-Marie Wadrawane
}

\section{Introduction}

Following on from pioneering projects (Allen and Gosden 1991; Garanger 1972; Green and Cresswell 1976), Melanesian archaeology has, during the last three decades, seen massive developments. In every archipelago, a number of ambitious research programs were initiated in the 1990s (e.g. Bedford et al. 1999; Clark and Anderson 2009; Sand 1996; Sheppard et al. 2000; Summerhayes 2000) and carried on in the following decades, allowing us to broaden, sometimes exponentially, our knowledge of the long past of this part of Oceania. Sadly, in a period characterised by important economic development in the region with the construction of numerous international hotels and tourism-related facilities, new roads and airstrips, extensions of townships, factories and housing, and logging and mining, very few large-scale archaeological rescue excavations in the form of cultural resource management (CRM) programs have been carried out. Impact studies are non-compulsory or mostly neglected in Oceania. In this regard, clear differences can be identified between the archipelagos of the region. Some nation-states have at times allowed highly destructive economic projects like logging or mining without any previous archaeological studies, while in other instances, multimillion dollar development projects by international companies include a multi-year archaeological assessment of the heritage landscapes before development (e.g. Richards et al. 2016).

As elsewhere in the Pacific, archaeology was considered problematic in New Caledonia for a long time and was consequently left to be dealt with by foreign research institutions. The political changes witnessed by the archipelago since the end of the 1980s, as part of a political decolonising dynamic, have fostered the creation of a local team of archaeologists and a slow rise in the occurrence of CRM excavations as part of some major development projects. In this paper we present the main steps that have led to positioning the archipelago as one of the regional leaders in CRM over the last decade (Figure 4.1), as well as an example of the type of archaeological results this approach has generated. 


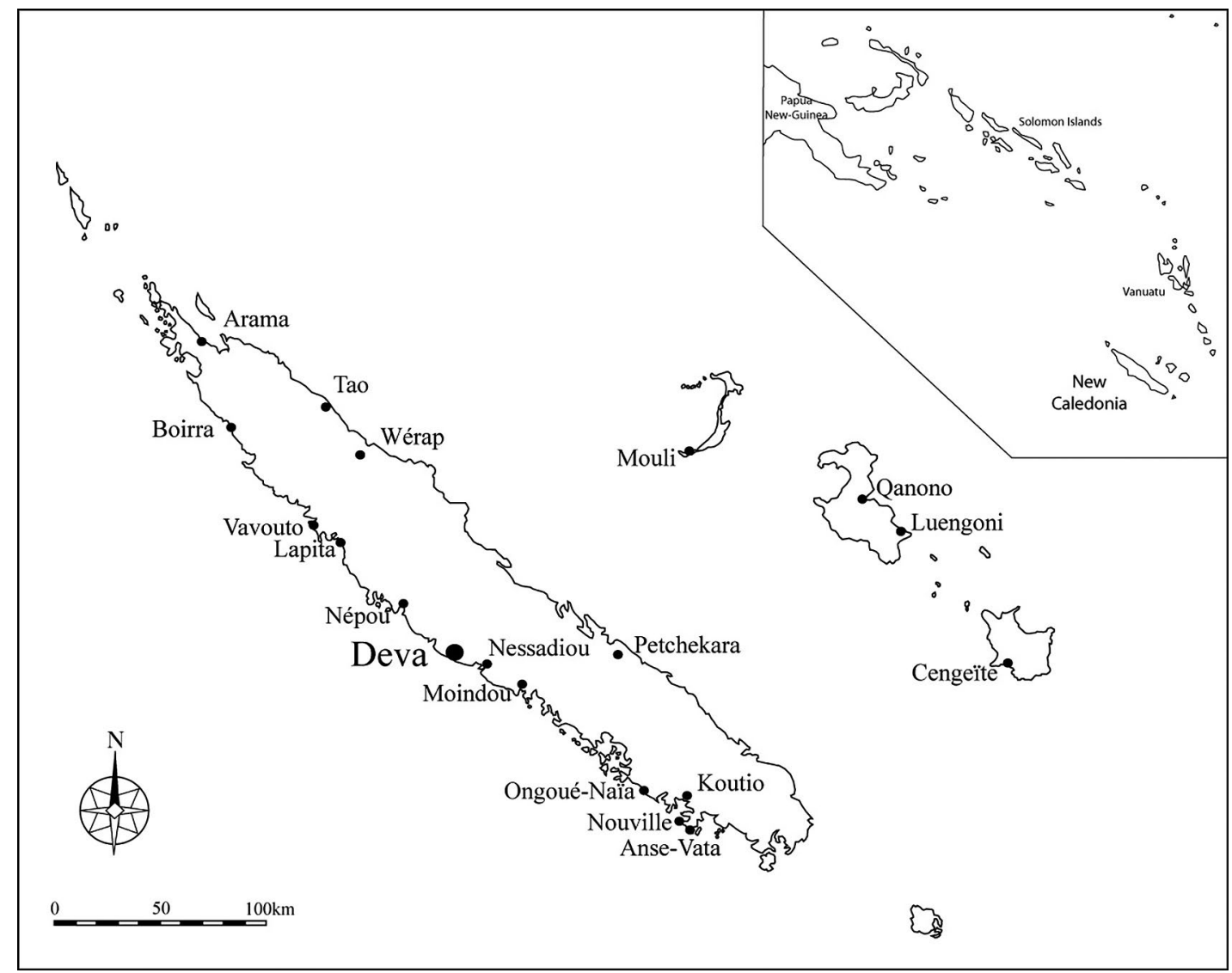

Figure 4.1. Location of sites where major rescue archaeology and CRM projects have been undertaken in New Caledonia.

Source: The authors.

\section{From small-scale rescue excavations to CRM: A synopsis for New Caledonia}

As in most of Melanesia, the insertion of archaeological heritage into impact studies for the development of economic projects has been slow to appear in New Caledonia. The political choice of negating archaeological remains that could potentially highlight indigenous history was one of the main drivers of the destruction of old sites during the colonial period of the archipelago (Sand et al. 2011a). Another significant aspect was that there was no dedicated local team to undertake excavations on development projects until the most recent decades. Consequently, professional archaeological programs in New Caledonia-which started in the 1950s - remained mainly research-based and the few rescue excavations were, for a long time, fulfilled as real 'rescue' operations, with often small-scale excavations opened during or after an archaeological site had already been severely disturbed.

Aside from observations done by local amateur archaeologists, the first real scientific project that incorporated the use of rescue excavation procedures in New Caledonia was Colin Smart's PhD project in 1966-67 on the site of Naïa in the south of Grande Terre. This beach location was heavily used as a sand quarry and Smart took this opportunity to open a number of trenches and a few larger-scale excavations (Figure 4.2). The varied data recovered, including a number of structures such as alignments of postholes, earth ovens and burials, allowed him to establish a ceramic 
chronology for the southern part of the archipelago (Green and Mitchell 1983; Smart n.d.). Another example of early rescue operation is the work of D Frimigacci at the site of Nessadiou in the 1970s, where he excavated a number of structures in what remained of the archaeological fill at the bottom of a sand quarry that had yielded Lapita sherds (Frimigacci 1999).

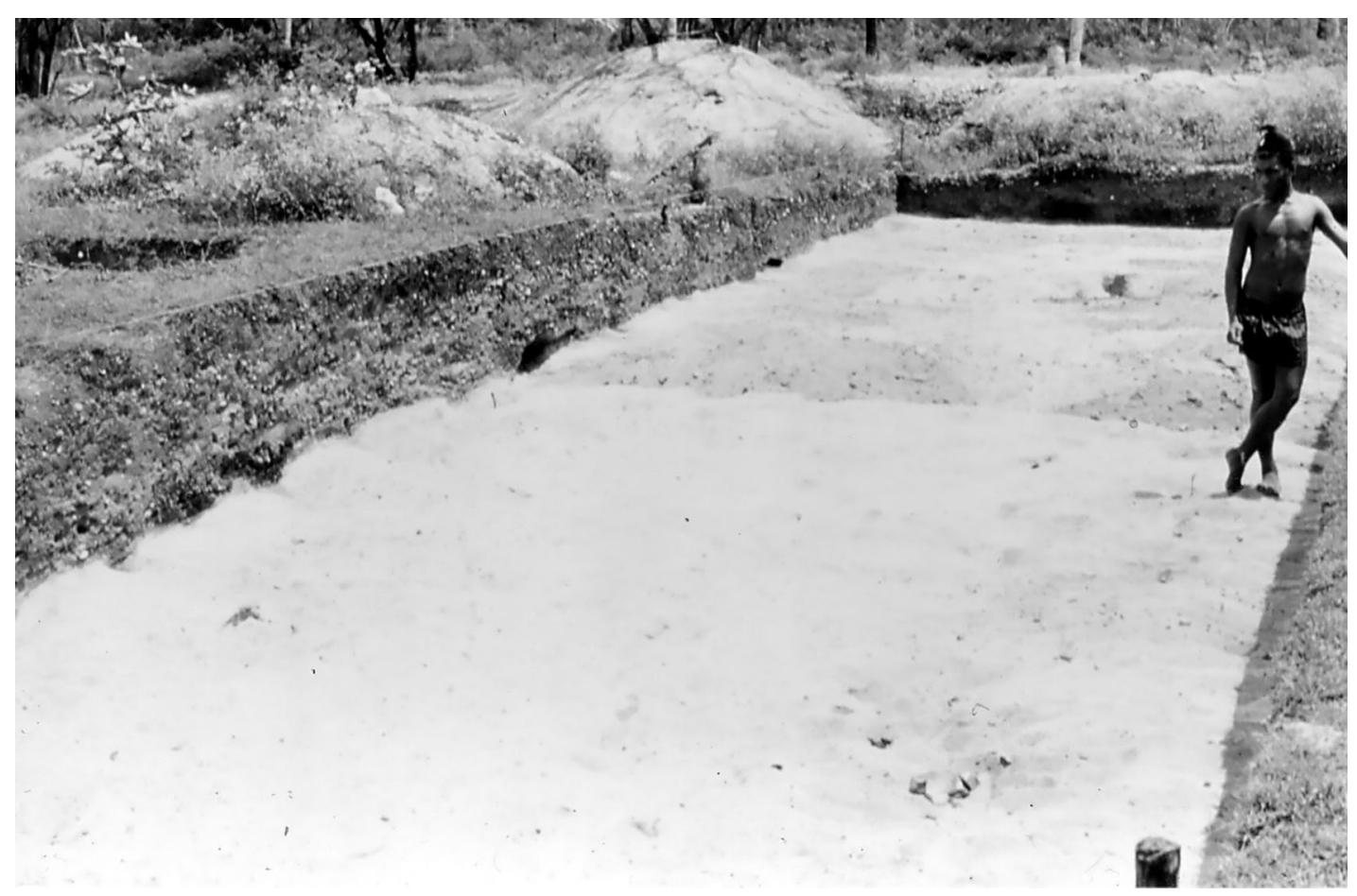

Figure 4.2. Large-scale excavation underway on site TON6 of Naïa by Colin Smart in 1966-67.

Source: Colin Smart; picture courtesy The Australian National University.

The 1980s were a time of political turmoil in New Caledonia, which hindered the development of field archaeology in the archipelago. Rescue excavations were mainly restricted to opening a few test pits on seashore locations that were under threat of economic development, especially around the capital Nouméa (Galipaud 1997). Things changed markedly in the 1990s, with the return of peace associated with a major phase of economic development that boosted the number of archaeological sites under threat. The creation of a local Department of Archaeology at the New Caledonia Museum in 1991, composed of three people, allowed archaeologists to work on some of these projects, mainly through publicly funded rescue excavations and low-scale archaeological impact studies. Rescue excavations were opened before the construction of hotels on each of the main islands of the Loyalties (Sand 1998a), while on Grande Terre it was mainly sand quarries and shrimp farm projects that prompted interventions (Sand 1998b; Sand and Ouetcho 1993; Sand et al. 1996). The main characteristic of the rescue programs undertaken during this decade is probably that the excavations remained mostly confined to a few square metres, in part due to the low funding provided. Nonetheless, these studies produced information that enhanced the understanding of some of the understudied periods of New Caledonia's chronology and allowed for the analysis of new topics (Sand 1996). Unfortunately, since impact studies were not compulsory, this period also witnessed a massive phase of destruction of important archaeological sites without any study.

A change in local procedures for impact studies emerged at the beginning of the 2000s, mainly driven by ecological lobbying. This had a positive effect on the development of archaeological interventions before economic projects. From then on, in a number of cases large-scale provincial 
projects in partnership with international companies—such as nickel smelters and multi-star hotels — had to be preceded by a comprehensive set of impact studies. International regulations certainly fostered this new approach, but it must be highlighted in the case of New Caledonia that local Kanak communities were also very much instrumental in the final incorporation of impact studies as part of the overall agreement to see these projects completed. In the early days of this new era, heritage was generally a poorly financed component of these studies, but the importance of the archaeological data recovered prompted in some cases a multi-year phasing of archaeological involvement, allowing for the emergence of a proper CRM methodology. This was characterised by the use of a backhoe and other heavy machinery to excavate large perimeters and by the development of trench digs to crisscross extensive surfaces. The need for large teams for these projects highlighted the difficulty of having CRM programs organised by the administratively constrained structure of the local Department of Archaeology. This prompted an experiment with the creation of private archaeological entities that was short-lived. In 2009 the New Caledonian government decided to preserve a public monopoly on archaeological digs.

One of the main archaeological CRM projects during this period was connected to the construction of a nickel smelter on the Vavouto Peninsula between the townships of Koné and Voh in the Northern Province (north-west coast of Grande Terre). Over the three phases, between 2002 and 2005 (Baret et al. 2000; Barp 2006; Carson 2003), a total of nearly $1600 \mathrm{~m}^{2}$ was excavated, mainly in trenches, uncovering many different sites and features ranging from a Lapita site to traditional pre-contact Kanak hamlets and horticultural field structures. Another important CRM project occurred in the Southern Province where the destruction of burials as part of a controversial housing project on the Poé dunes (central west coast of Grande Terre) led to extensive trenching of the affected site in different phases between 2006 and 2008. This led to the discovery of deep stratified deposits and other burials (Barp 2009; Sand et al. 2008, 2012).

\section{Switching to a larger scale: The Deva project}

These first cases of proper CRM experiments led to a change of paradigm. The significant public impact of the Poé excavations prompted the Kanak stakeholders of the central west coast region of Grande Terre and the municipality of Bourail to include a compulsory archaeological impact assessment component in the general protocol of the economic development project of the nearby provincial property of Deva. The project included the construction of a 5-star hotel and an 18-hole international golf course on the seashore plains of Deva, facing one of the reef/lagoon marine clusters of New Caledonia, which were inscribed on the UNESCO World Heritage List in 2008. The start of the project coincided with a boost in the number of archaeologists working at the Department of Archaeology, soon to be transformed into the Institute of Archaeology of New Caledonia and the Pacific (IANCP). There was thus for the first time enough trained personnel to envision a long-term CRM project in New Caledonia through a public research institution, something that, to this day, is still unique in the Melanesian context.

\section{The extent of the Deva excavations}

The scale of the project meant that we had to adapt our methodology to be able to cover huge areas (cf. Sand et al. 2013:15-25). The Deva property, owned by the Southern Province, covers a surface of about 7450 hectares, encompassing a $15 \mathrm{~km}$ strip of coastal plain and a series of inland valleys and hills stretching up to $5 \mathrm{~km}$ from the coast. Although very depopulated at French colonisation, the Deva region is identified in Kanak oral traditions as an important traditional nexus during the centuries before first European contact. A general survey of the property allowed us to record over 200 Kanak sites, mainly in the plains and hilltops (Domergue 2009). 
At first, the development projects were concentrated mainly on some parts of the seashore plain, where the hotel complex planned to occupy about 45 hectares and where 110 hectares were devoted to the golf course.

Since surface surveys had identified only minimal traces of archaeological occupations on the seashore plain, it was decided to begin the archaeological study by opening trenches with a backhoe in order to get a general understanding of the stratigraphy. The backhoe bucket was positioned to remove about $10 \mathrm{~cm}$ of sediment at every pass in order to observe and record any change in stratigraphy and to identify the appearance of archaeological features (ovens, burials, etc.). In 2008, a set of $15210 \mathrm{~m}$ trenches were excavated every $50 \mathrm{~m}$. In 2010, another set of 108 trenches were positioned more precisely on the location of the future bungalows of the hotel and on the area planned to receive the larger buildings for the hotel rooms. In 2012, 71 trenches covering $600 \mathrm{~m}^{2}$ were excavated over an area of about 8 hectares at the north-west extremity of the coastal development area, where the golf course was soon to be located.

The excavations identified a sand-fill up to about $300-400 \mathrm{~m}$ away from the present beach, marked on the ground by successions of low dunes positioned parallel to the coast. This fill is replaced by marshy deposits or in situ basal rock formations towards the hillside. In the sand dunes, the archaeological fill was not deeper than about $65 \mathrm{~cm}$ regardless of the location where the trenches were excavated. The main stratigraphy was composed of a light terrigenous surface layer overlying usually one to three sandy deposits with pottery, shells, occasional stone artefacts and, in some instances, stone ovens, small post holes or human burials.

Aside from the trenching program, two large-scale archaeological excavations were opened as part of the hotel and golf course development projects. The first was $656 \mathrm{~m}^{2}$ and was located in the back part of the dune area, where a concentration of archaeological remains, including stone ovens and burials, had been identified during trenching. As this was the planned location of one of the large hotel buildings, we decided to investigate the archaeological significance of the area. The excavations highlighted the presence of a well-preserved layer dated from 600-400 BCE with some large stone ovens as well as a number of postholes, but without any sign of large habitation structures. A total of seven burials, all dated from the second millennium CE, were also excavated. They were distributed randomly across the site and did not show any indication of a deliberate 'burial ground'. In consequence of the discovery of the burials, the hotel promoters decided — at the explicit demand of the Kanak stakeholders - to move the planned hotel building to a new location in order to prevent the disturbance of the skeletons.

The presence of other burials in different trenches opened in the golf course area fostered the second large-scale excavation of Deva. In order to prevent the possible destruction of burials in the course of quarrying sand for the bunkers of the golf course, the Kanak customary leaders asked the Southern Province to agree to the complete excavation of a nearly one-hectare block. This led to what is probably to this date the largest open area (about $130 \mathrm{~m}$ by $65 \mathrm{~m}$ ) excavation ever undertaken in Melanesia, with a total area of just under $8000 \mathrm{~m}^{2}$ (Figure 4.3). The study highlighted the absence of deeply buried remains over a large surface and confirmed the patterns exposed by the trenching program regarding settlement patterns and chronologies. 


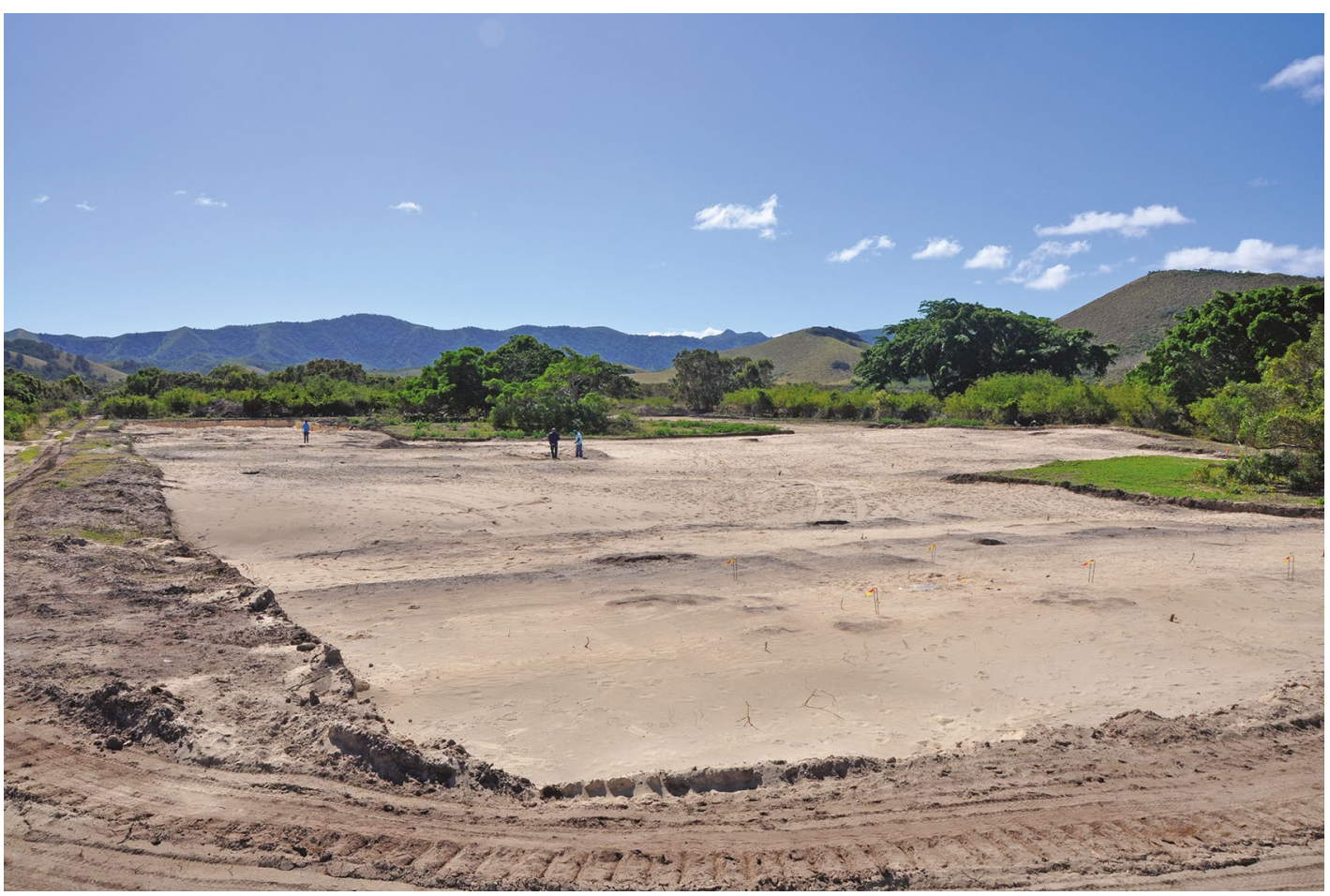

Figure 4.3. The nearly 1-hectare excavation of the Deva sand quarry at the end of the CRM project. Source: Photograph Christophe Sand, IANCP.

\section{Deva's settlement pattern data}

The extensive set of excavations opened in the seashore dunes of Deva as part of the CRM project have allowed us to gain a unique understanding of the formation processes of this coastal strip of Grande Terre, facing the area of the lagoon where the reef is closest to land (about 2-3 km). The identification of a massive change in the coastal environment over the past 3000 years, which corresponds to the period of human settlement, is probably the most significant result in terms of environmental setting (Figure 4.4). The excavations have clearly demonstrated that at the end of the last ocean highstand, around 4000-3500 years ago, the seashore was located about $300-400$ metres further inland from its present position. The drop of the sea level to its present level over the centuries led to the formation of small dunes, on which the first Lapita occupants of the area known today as Deva settled between 950 and 850 BCE. At that time, the actual surface for settlement was in most places probably less than 50 metres wide, since the land behind the narrow dunes was marshy. Through the following millennium, new dunes progressively formed in front of the original sand spit, resulting in the expansion of the area by about 100 metres. This prompted the occupants to constantly move their dwellings to the most recently formed dunes, in order to keep direct access to the seashore and created what we have termed a 'horizontal stratigraphy'. This process of repetitive seaward moves sealed most of the previous archaeological remains, prevented massive disturbances by later occupations and explains the absence of deep stratigraphy anywhere in the hotel and golf course areas. During the first and second millennia $\mathrm{CE}$, the continuing natural process of dune formation-linked to natural sand production but without any tectonic process involved - led to the further expansion of the width of the area by up to $200 \mathrm{~m}$ in some places. 


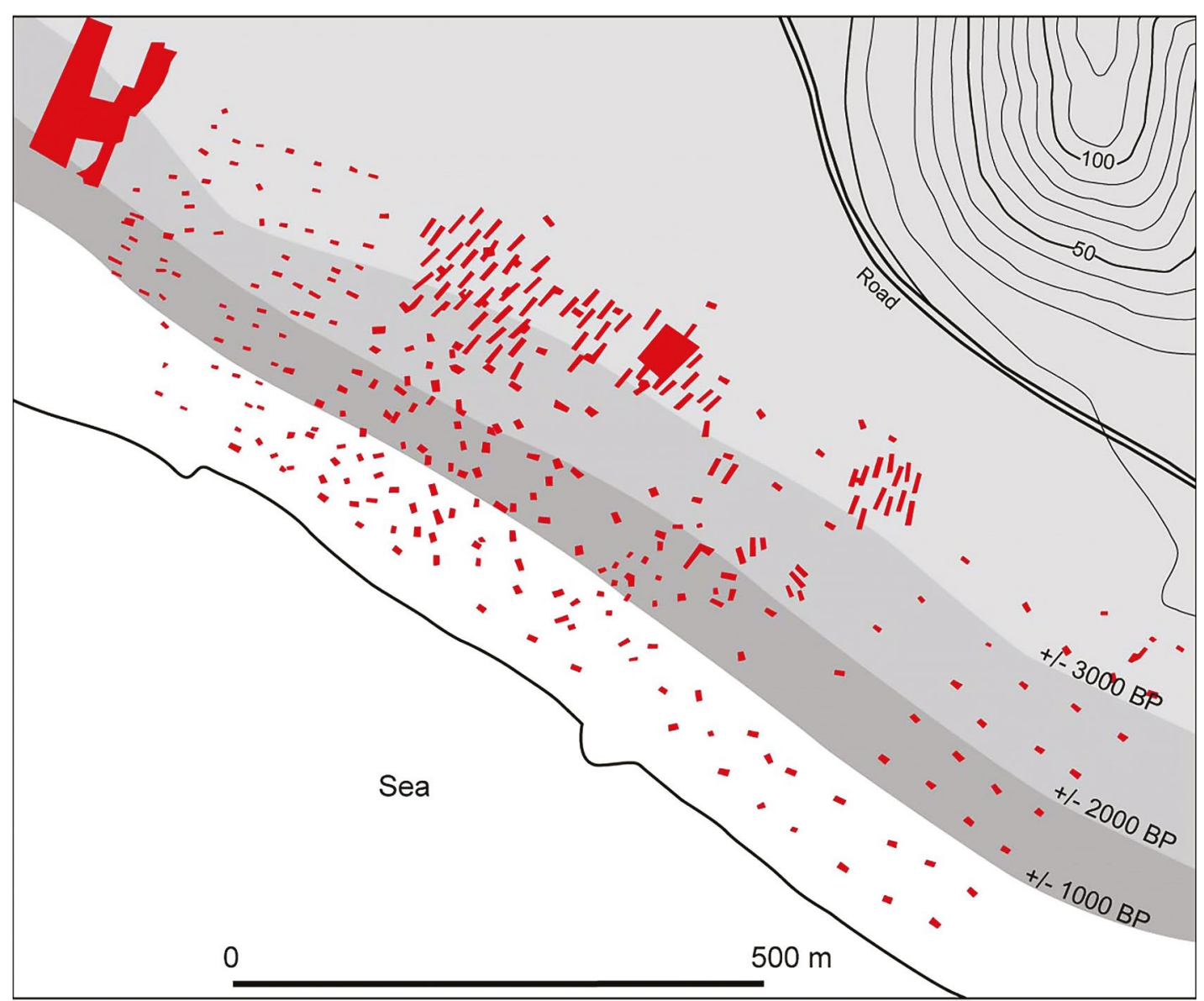

Figure 4.4. Synthesis map of the different excavations undertaken between 2008 and 2012 on the hotel and golf course settings of Deva, with the general chronological progression of the coastal dunes over the last 3000 years.

Source: The authors.

The fairly low amount of archaeological material uncovered for such a long chronology, as well as the low density of shell remains and the limited number of cooking and heating structures in most excavated zones, are clear testimonies to the discontinuous occupation of this coastal strip over a significant part of its human occupation. For nearly two millennia, the groups foraging the seashore of this easily accessible lagoon environment appear to have been living a semi-nomadic lifestyle, moving up and down the coast, possibly to prevent overharvesting the lagoon's limited ecological environment. Nowhere in the excavations has it been possible to identify any trace of permanent housing structures. While a number of clear postholes were uncovered on a regular basis, they never formed a coherent set of housing patterns. They appeared more like components of simple shelters. In a number of instances, postholes were covered by stone ovens, indicating resettlement after a period of abandonment.

Data allow us to subdivide this general scheme of occupation into different phases. The first millennium BCE is characterised by few occupations of groups that were probably mainly seashore foragers with a low-level reliance on horticulture. This general hypothesis is supported by the near-absence of sites related to this time period in the valleys behind the beach. A change in demography is clearly apparent during the first millennium CE, with the progressive increase of the number of burials, mainly positioned in the dunes that were at the back of the beachfront at that time. Of the 25 skeletons excavated, 15 are dated to the central part of the first millennium 
CE. This time period saw on Grande Terre a crisis possibly linked to demographic growth and environmental factors, but also saw the slow appearance of new intensified horticultural techniques that contributed to the emergence of the 'Traditional Kanak Cultural Complex' at the beginning of the second millennium CE (Sand et al. 2003). The last millennium of occupation was characterised by sedentary multi-secular hamlet occupations. Significantly, only a few scarce signs of Kanak occupation have been uncovered in the more recent dunes, located in the first 100 metres behind the present beach. This clearly sets apart the settlement pattern of this recent period compared to the multiple remains of the two preceding millennia excavated in the Deva dunes (Sand et al. 2018). The archaeological data do not suggest that there were no coastal settlements during the traditional Kanak period, but rather that these were mainly restricted to clearly defined hamlets, probably positioned at the estuaries of the permanent creeks of Deva which are outside the area excavated by our CRM project. Numerous indications of densified Kanak settlements, with some extensive villages and associated horticultural structures, have been identified in the inner valleys of Deva (Sand et al. 2013:9-14).

\section{The cultural chronology of the central west coast of Grande Terre}

This project allowed us to study for the first time the whole cultural chronology of this central portion of the west coast of Grande Terre, at the border between the northern and southern ceramic regions of the archipelago (Sand et al. 2011b). The process of horizontal stratigraphy permitted by the progressive building of new sand dunes over a 3000-year period, and its consequent low mixing of material from different chronological periods, resulted in a clarification of a number of typological uncertainties for the local ceramic sequence (see Sand et al. 2013:38-49 for details). This has been achieved thanks to more than 350 radiocarbon dates obtained during the multi-year program.

\section{Pottery}

The amount of dentate-stamped vessels related to the first Lapita settlement is limited to a few sherds. This is not surprising as the oldest dates obtained are calibrated around 950-850 BCE, at the end of the Lapita period. These are associated with a great number of paddle-impressed sherds of the Podtanean tradition, some also bearing decorations from shell impressions or incisions. The rim profiles that could be reconstructed for some of these vessels in Deva show outcurved rims and poorly angled carination at the beginning of the occupation, with a progressive disappearance of the carination and increasing numbers of vessels with straighter rims. The chronological overlap between Podtanean and the succeeding incised Puen wares is clearly visible in the layers dated to the second half of the first millennium BCE. Puen pots show a significant diversity in form, size and decoration, but retain the mainly globular profile with simple incurved rim.

The start of the first millennium CE saw the progressive emergence of the handled Plum tradition pots, which becomes the main pottery type during most of the millennium. The Deva excavations have confirmed the parallel production of Puen and Plum pots during a few centuries in the Bourail region. They have also shown that, unlike in the southern part of Grande Terre, Plum vessels in this central region, while poorly decorated, have a unique type of tenon beside the usual horizontal handles. This consists of a bulky kind of rounded nubbin, known until now only through museum collections (Chevalier 1966-70). The last ceramic period, characterised by the Nera tradition of oval pots with incurved rims and alignments of raised nubbins, is the least represented in the excavated areas. A few Oundjo sherds at Deva indicate that some pots produced in the northern half of Grande Terre were brought to the site, probably through exchange. 


\section{Shell ornaments}

A significant quantity of shell ornaments has been retrieved during the Deva excavations. They display a diversity of production types, ranging from mainly Conus armbands and discs, to numerous small beads extracted from Conus leopardus and Conus eburneus shells. Tridacna ornaments are restricted to the first millennium BCE. In regards to shell artefacts, two outcomes can be highlighted. The first is related to the in situ production of these items, as numerous grinding and polishing plaques of diverse sizes were used during the manufacturing process. The second relates to the site itself; Deva being known in Kanak oral traditions as one of the important places of traditional shell money manufacture, with people coming even from the east coast of Grande Terre to collect specific shells in the lagoon. The excavation at the sand quarry uncovered the working floor of an area where shell beads were produced dated to about 2400 years ago. The archaeological data for New Caledonia supports the hypothesis that beads were used as shell money during that time period, but this is the first time an actual production centre has been identified. Significantly, shell money typology changed with the advent of the 'Traditional Kanak Cultural Complex', something that has been clearly documented in Deva. Again for the first time for the archipelago, remains of a complete shell money kit was excavated just over the wrapped bones of an adult dated to the early 19th century. It consisted of a series of finely carved oyster shell pendants, each between $20 \mathrm{~mm}$ and $30 \mathrm{~mm}$ long, that were probably attached to a vegetal packet as is known through museum specimens.

\section{Stone artefacts}

Compared to the shell artefacts, the number of stone artefacts uncovered during the Deva excavations is low. This is probably partly due to the poor quality of the rocks that could be extracted for flaking and polishing in the immediate geological area surrounding this portion of the west coast. Excavations have nonetheless allowed us to uncover a few adzes dating from the central part of the Koné period (second half of the first millennium BCE), filling a void in our chronology of polished items. Of interest was also the discovery of a large fragment of a drilled nephrite polished axe, clearly similar to the Kanak ceremonial 'ostensoir axes', in a layer dated to the 15th century CE. This is only the third occurrence of such an item in a datable stratigraphic context in New Caledonia.

\section{Burials}

The last major contribution of the CRM excavations at Deva relate to burial customs. In total, 25 burials were excavated. The agreement with the Kanak customary authorities was that we were allowed to excavate each identified skeleton and to map and photograph the in situ remains without removing the bones. We got the permission to collect three small bones, one used for dating, one for isotope studies and one for possible DNA analysis in the future. After completion of the archaeological study, each skeleton was reburied in sand. A diversity of funerary practices only partly related to chronological changes was identified throughout the site (Sand et al. 2013:66-69). During the period corresponding with the most intense use of the area as a burial place from the first millennium CE to the beginning of the second millennium CE, most bodies were placed in a pit in a flexed seated position (Figure 4.5). Some bodies show clear signs of wrapping, possibly with a mat or some sort of rope. The few burials from the later part of the second millennium CE show more significant body manipulation in some instances, with the presence of partly reorganised remains wrapped in square packs. 


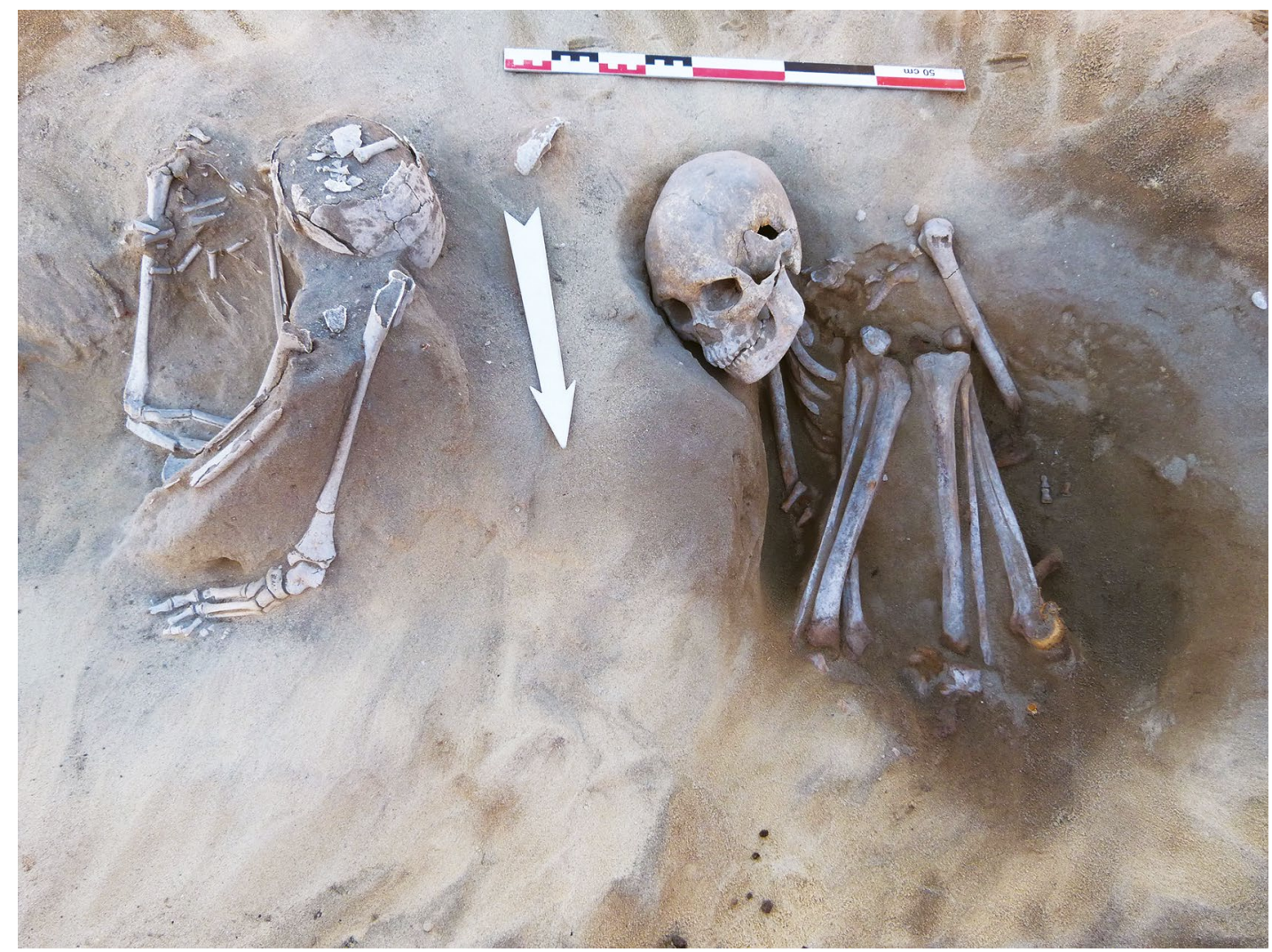

Figure 4.5. Example of flexed burials in pits, excavated in the south-western area of Deva's sand quarry.

Source: Photograph Jacques Bolé, IANCP.

\section{Conclusion}

By highlighting the CRM case study of Deva in New Caledonia, this paper has discussed a neglected aspect of archaeological potential in Melanesia. The slow emergence of a proper interest in archaeological impact studies in the archipelago over the last few decades has been linked to the unique historical and political situation of this southern Melanesian archipelago. While the international regulations were implemented as part of the preparatory process in the case of the two large multimillion dollar nickel smelter projects, Kanak customary pressure was unquestionably instrumental in the imposition of archaeological impact studies for the Deva property development (Sand 2015). One of the direct outcomes of the CRM programs for the Deva hotel and golf course projects has been to move one of the main buildings to a new location and to limit the extent of the sand quarry surface in order to protect a set of burials. Moreover, each identified burial of the coastal dune area is now protected by a $4 \mathrm{~m}^{2}$ perimeter, on which nothing can be built.

It can be asked if the same development of archaeological impact studies is to be expected elsewhere in Island Melanesia in the near future. To this day, the only direct parallel in terms of scale is the archaeological research at Caution Bay near Port Moresby on mainland New Guinea (Richards et al. 2016), where a well-funded archaeological CRM program was undertaken ahead of the construction of a liquefied natural gas plant and pipeline. In this case, the work was done by an international team, with only some local expert input. The main challenge to the future development of CRM programs appears to be in the field of local archaeological expertise in the Melanesian countries. As long as local governments do not promote training, including 
postgraduate education, and support for permanent archaeological staff in their museums and cultural centres, archaeology will continue to remain mainly an outsider-driven topic in the region. Only well trained and well equipped teams will have the capacity and the administrative power to promote effective archaeological resource management and rescue archaeology ahead of development in Island Melanesia. Economic pressure as well as political constrains will continue to dominate the agenda and local archaeologists will have to maintain their lobbying to see any progress in this domain in the years to come.

The progressive shift of the administrative understanding of what should be the mandate of archaeology in New Caledonia is a less obvious consequence of the rise of CRM programs that has major negative implications. Like other developed regions around the world, the rise of archaeological impact studies has sadly led decision-makers to think that archaeology is mainly devoted to this type of economically driven fieldwork for the sake of 'clearing the site' for development (Hutchings and La Salle 2015). Consequently in New Caledonia, the emergence of CRM has gone hand in hand with the massive drop in public finances for archaeological projects associated with research questions. Over the last years, the program of the IANCP has been nearly entirely devoted to CRM activities, trapping the local archaeological team into a neverending series of archaeological impact studies. The saddest outcome of this change of focus is that the amount of archaeological data recovered though CRM has become so extensive, and the time that can be devoted to its study has shrunk so much, that publications are limited to 'grey literature' reports for the developers. This progressive change in paradigm highlights the slow move of CRM archaeology towards the private sector, something that is today promoted by the provincial cultural services. This will undoubtedly reinforce the trend towards 'grey literature' publications, depriving the local populations as well as the archaeologists working in Melanesia of the massive amount of new data that CRM will continue to generate in the decades to come.

\section{Acknowledgements}

The archaeological research programs and CRM projects on the Deva property have been fulfilled through the financial support of the Southern Province and the Government of New Caledonia to the authors' institute. The fieldwork presented here was undertaken by the authors under the direction of the first author, who wrote the present paper. The SEM (Société d'économie mixte) Mwé Ara, who is in charge of the management of the property, has given all the help possible during the fieldwork. The traditional Kanak landowner families and clans related to Deva, grouped in the GDPL (Groupement de Droit Particulier Local) Mwé Ara, have given their permission for the surveys and excavations.

\section{References}

Allen, J and C Gosden (eds). 1991. Report of the Lapita Homeland Project. Occasional Papers on Prehistory 20. Canberra: Department of Prehistory, Research School of Pacific Studies, The Australian National University.

Baret, D, J Bolé, A-J Ouetcho and C Sand. 2000. Etude de potentiel et pré-inventaire des ressources patrimoniales du milieu. Etude environnementale de base. Koné: Projet Koniambo.

Barp, F. 2006. Etude archéologique phase 3. Rapport final d'opération. Nouméa: Project Koniambo.

Barp, F. 2009. Site 'Ecrins de Poé', WBR047, Commune de Bourail, Province Sud, Nouvelle-Calédonie. Nouméa: Rapport de 'Strates, archéologie préventive, Nouvelle-Calédonie' pour le compte de la province Sud de la Nouvelle-Calédonie. 
Bedford, S, M Spriggs and R Regenvanu. 1999. 'The Australian National University-Vanuatu Cultural Centre Archaeology Project 1994-97: Aims and results’. Oceania 70 (1):16-24. doi.org/10.1002/ j.1834-4461.1999.tb02986.x.

Carson, M. 2003. Phase two archaeological study, Koniambo Project, regions of Voh, Koné, and Pouembout, Northern Province, New Caledonia. Honolulu: International Archaeological Research Institute, Inc.

Chevalier, L. 1966-70. 'Les éléments de préhension de la poterie calédonienne'. Etudes Mélanésiennes 21-25:45-54.

Clark, G and A Anderson. 2009. The early prehistory of Fiji. Terra Australis 31. Canberra: ANU E Press. doi.org/10.22459/TA31.12.2009.

Domergue, S. 2009. Mission Deva 2006. Premier inventaire des vestiges archéologiques. Nouméa: Département archéologie de la direction des affaires culturelles et coutumières.

Frimigacci, D. 1999. 'Où sont allés les potiers Lapita de Bourail? Remarques sur le site WBR001'. In Le Pacifique de 5000 à 2000 avant le présent. Suppléments à l'histoire d'une colonisation, edited by J-C Galipaud and I Lilley, 63-84. Paris: Editions de l'IRD.

Galipaud, J-C. 1997. 'A revision of the archaeological sequence of Southern New Caledonia'. New Zealand Journal of Archaeology 17 (1995):77-109.

Garanger, J. 1972. Archéologie des Nouvelles-Hébrides: Contribution à la connaissance des îles du Centre. Publications de la Société des Océanistes 30. Paris: Société des Océanistes, Musée de l'Homme. doi.org/10.4000/books.sdo.859.

Green, RC and MM Cresswell. 1976. Southern Solomon Islands cultural history: A preliminary report. Bulletin 11. Wellington: Royal Society of New Zealand.

Green, RC and J Mitchell. 1983. 'New Caledonian culture history: A review of the archaeological sequence'. New Zealand Journal of Archaeology 5:19-68.

Hutchings, R and M La Salle. 2015. 'Archaeology as disaster capitalism'. International Journal of Historical Archaeology 19 (4):699-720. doi.org/10.1007/s10761-015-0308-3.

Richards, T, B David, K Aplin, and I McNiven. 2016. Archaeological research at Caution Bay, Papua New Guinea: Cultural, linguistic and environmental setting. Caution Bay Studies in Archaeology 1. Oxford: Archaeopress.

Sand, C. 1996. 'Recent developments in the study of New Caledonia's prehistory'. Archaeology in Oceania 31:47-71. doi.org/10.1002/j.1834-4453.1996.tb00349.x.

Sand, C. 1998a. 'Recent archaeological research in the Loyalty Islands of New Caledonia'. Asian Perspectives 37:194-223.

Sand, C. 1998b. 'Archaeological report on localities WKO013A and WKO013B of the site of Lapita (Koné, New Caledonia)'. Journal of the Polynesian Society 107:7-33.

Sand, C. 2015. 'On the edge of a World Heritage Site: Local communities and archaeological practice related to the nomination of the New Caledonia Reef'. In Second International Conference on Best Practices in World heritage: People and Communities, edited by AC Mena, 874-887. Madrid: Universidad Complutense de Madrid.

Sand, C, J Bolé and A-J Ouetcho. 1996. Le début du peuplement austronésien de la Nouvelle-Calédonie. Données archéologiques récentes. Les cahiers de l'archéologie en Nouvelle-Calédonie 6. Nouméa: Service territorial des musées et du patrimoine.

Sand, C, J Bolé and A-J Ouetcho. 2003. 'Prehistory and its perception in a Melanesian Archipelago: the New Caledonia example'. Antiquity 77 (297):505-519. doi.org/10.1017/S0003598X00092565. 
Sand, C, J Bolé and A-J Ouetcho. 2011a. 'Evolutions du discours archéologique sur 150 ans d'histoire colonial et postcoloniale en Nouvelle-Calédonie. Un cas d'école'. Les nouvelles de l'Archéologie 126:37-40.

Sand, C, J Bolé and A-J Ouetcho. 2011b. 'A revision of New Caledonia's ceramic sequence'. Journal of Pacific Archaeology 2:56-68.

Sand, C, JA Grant-Mackie, HJ Campbell and J Turnbull. 2018. 'Seashore settlement patterns in the Koné and Naïa Periods: Case studies from Southwestern New Caledonia'. Journal of Island \& Coastal Archaeology 13 (4):1-13. doi.org/10.1080/15564894.2018.1513101.

Sand, C, and A-J Ouetcho. 1993. 'Three thousand years of settlement in the south of New Caledonia: Some recent results from the region of Païta'. New Zealand Journal of Archaeology 15:107-130.

Sand, C, A-J Ouetcho, J Bolé, D Baret, L Lagarde and F Valentin. 2012. 'Archéologie en Mélanésie: Données du site côtier WBR047 des “Ecrins de Poé” (Bourail, Nouvelle-Calédonie)'. Bulletin de la Société préhistorique française 109 (3):495-512. doi.org/10.3406/bspf.2012.14172.

Sand, C, A-J Ouetcho, J Bolé, D Baret and F Valentin. 2008. Données archéologiques sur le site WBR047 des 'Ecrins de Poé' (Commune de Bourail, province Sud): Tentative de synthèse sur l'intervention de 2007. Nouméa: Département archéologie de la direction des affaires culturelles et coutumières.

Sand, C, M Terebo and L Lagarde (eds). 2013. La passé de Deva. Archéologie d'un domaine provincial calédonien. Archeologia Pasifika 2. Nouméa: Institut d'archéologie de la Nouvelle-Calédonie et du Pacifique.

Sheppard, P, R Walter and T Nagaoka. 2000. 'The archaeology of head-hunting in Roviana Lagoon, New Georgia, Solomon Islands'. Journal of the Polynesian Society 109:9-37.

Smart, C. n.d. 'Notes on the pottery sequence obtained for southern New Caledonia' (Report confidential 1969) (ms).

Summerhayes, G. 2000. Lapita interaction. Terra Australis 15. Canberra: Department of Archaeology and Natural History and Centre for Archaeological Research, The Australian National University. 
This text is taken from Archaeologies of Island Melanesia: Current approaches to landscapes, exchange and practice, edited by Mathieu Leclerc and James Flexner, published 2019 by ANU Press, The Australian National University, Canberra, Australia.

doi.org/10.22459/TA51.2019.04 